\title{
Harmonization of Inspection Supervision in the Pharmaceutical Sector of the Republic of Macedonia in conformity with the Recommendations of the European Legislation and WHO
}

\author{
Vasilka Nicha, Renata Slaveska Raichki* and Tatjana Kadifkova Panovska \\ Public Institution in the Health Sector, for the needs of PHI University Clinics, Institution and Urgent Centre, Skopje \\ Faculty of Pharmacy, University "Ss Cyril and Methodius", Skopje
}

Received: November 2011; Accepted: De pan>

\begin{abstract}
The new Law on Inspection Supervision (Official Gazette 50/2010, implementation as of 1.04.2011) was passed in April 2010 with the aim of improving the quality of inspection in the pharmaceutical sector, as well.

The new Law covers the spectrum of weaknesses recognized over time. The system of quality inspection encompasses a set of commonly required quality management process, objectives, conditions, policies, formal rules and procedures. The organizational scheme addresses all aspects of inspection activity. The inspection service has to assure that its personnel are not under any undue internal or external commercial, financial or other kind of pressure and influence that may adversely affect the quality of their work. Moreover, the inspection service needs a sufficient number of employees with the necessary education, training, technical knowledge and experience to perform inspection activities according to specified requirements and standards. An inspector's engagements have to be within the scope of the responsibilities arising from his/her activities. Continued training in inspection activities should be established, including advanced training programs that offer various levels of inspectors' qualification. In regard to their specific activity, new rule books governing inspection supervision in the pharmaceutical sector should be developed and adopted in the near future.

This permanent upgrading process of the existing national policies in compliance with the EU legal policy has also become characteristic of the Macedonian pharmaceutical sector.
\end{abstract}

Key words: pharmaceutical inspection supervision

\section{Global Characteristics of the Pharmaceutical Sector}

The findings confirm that the so called «life cycle of medicine» - Fig. 1 is, in essence, a strictly regulated technical system with many elements of complex nature. To begin with, this system encompasses elements for new medicines research and development. The most successful candidates for becoming medicines are subjected to clinical trials and patent procedure. Medicine production licensing is another very important element of this system. Putting the medicines in a strictly organized process of indus-

\footnotetext{
* rera@ff.ukim.edu.mk
}

trial production is burdened by numerous challenges, resulting in difficulties in establishing the conditions, criteria and procedures. The medicine becomes available to the end user once the marketing authorization is obtained.

The price of the medicine is determined using selected national methodology (IDPI, 2009). In keeping with the priorities in population health care, some of the medicines with marketing authorizations are selected and included in the national list of essential medicines, as per the World Health Organization recommendations (WHO, 2004; WHO, 2010).

The components of the pharmaceutical system known as medicines supply and distribution provide smooth access and availability of medicines (of domestic origin or imported) for the end users (OGRM, 2007a; WHO, 1999). 


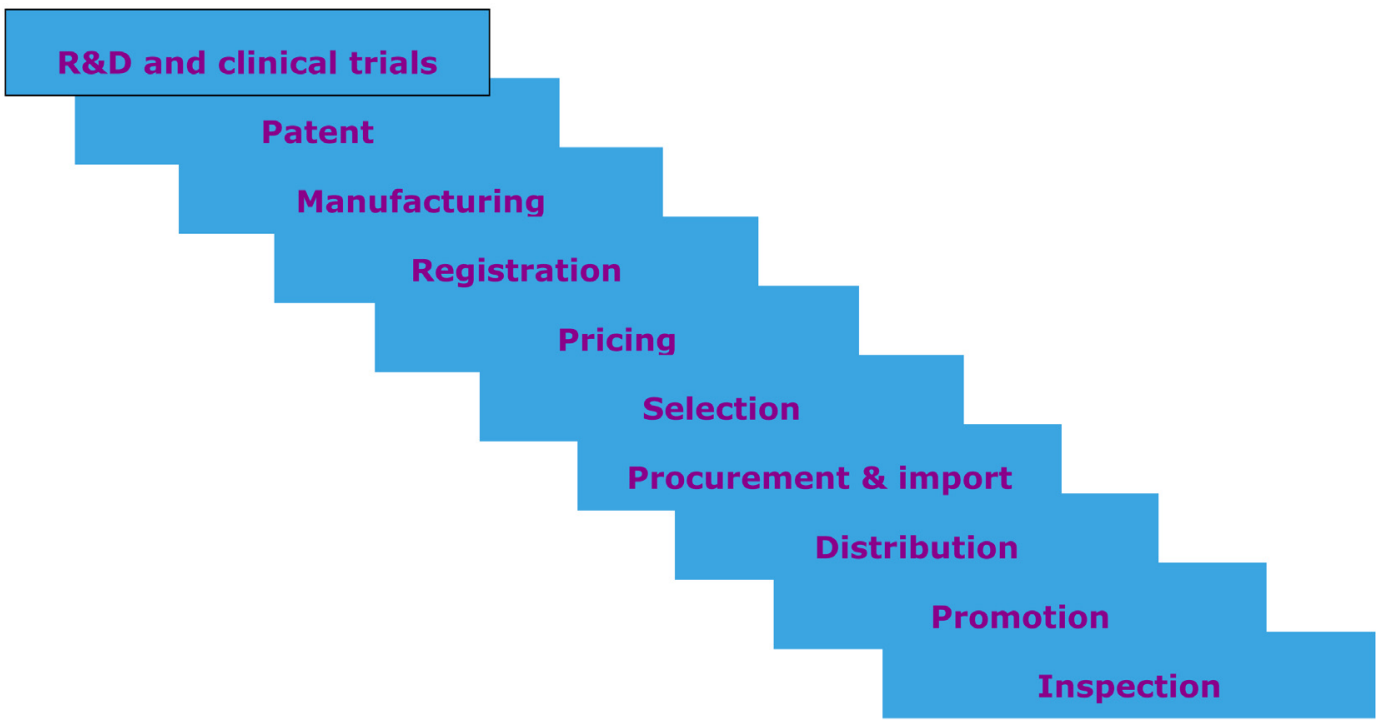

Fig. 1. Life cycle of medicine

The element of providing ethical promotion of medicines to health professionals and end-users (patients) is no less important.

In the light of the existence of globally harmonized legislation and technical guidelines on the separate functions in the pharmaceutical sector: GMP (Good Manufacturing Practice), GCP (Good Clinical Practice in Clinical Trials), GQCLP (Good Quality Control Laboratory Practice), GLP (Good Laboratory Practice), GSP (Good Storage Practice), GDP (Good Distribution Practice), GPhP (Good Pharmacy Practice), guidelines for ethical promotion of medicines and the like, it is recognized that the integration of all these elements in the national pharmaceutical sector and their successful application and evaluation in practice is of vital importance. Bearing in mind that the issue here is the essential regulation of the pharmaceutical sector, the inspection supervision in the spectrum of functions is recognized as one of the paramount activities of the competent bodies in this sector.

The aim of the inspection supervision in the pharmaceutical sector, i.e. inspection of medicines and medical devices production, import, export, distribution, advertising and the like, is to ensure that these functions are performed in compliance with the national legislation and the approved standards and guidelines. To that end, the primary objective is to ensure that medicines intended for the population in the country are safe, efficient and of controlled quality. In addition to the responsibilities in the official market of medicines, inspectorates should guarantee that there are no illegal activities such as smuggling of medicines, medicines sale in uncontrolled open markets, as well as no counterfeited medicines and medicines that do not meet the required quality standards.

The first step to be taken by the national authorities in order to institute an efficient inspection supervision, is to establish a legal basis. In other words, a consistent implementation of inspection supervision in the area of medicines and medical devices requires development and ongoing improvement of the laws and regulations within the national legislation. The regulations in the area of inspection supervision should, at the same time, prevent any possibility of inspectors' illegal activities and abuse of official powers, and ensure appropriate sanctions in cases of such activities. In line with these principles and the global experiences of many years, it is realized that it is imperative to implement a system of control of the inspection activities that will combine a set of basic requirements with regard to quality assurance and management with the inspectorates in their accomplishment of the set goals, tasks and conditions. That is to say, the system should be founded on respect for the existing legislation and other elements stemming from and integrated into this sphere. The organizational structure of inspection services should cover all aspects of their activities.

\section{Development of a National Inspection Supervi- sion in the Pharmaceutical Sector}

At present, the primary task and one of extreme importance is the harmonization of the provisions of the Law on Inspection Supervision (OGRM, 2010) with the Law on Medicines and Medical Devices (OGRM, 2007b) and the passing of by-laws foreseen with the Law on Inspection Supervision. These two laws should be the realistic basis for the building of a quality system for the pharmaceutical inspection services, embodied in a concrete quality manual (Inspectorate Quality Manual) (PIC/S, 2007). The implementation of the quality system for the pharmaceutical inspection services and the compliance with the EU di- 
rectives should ensure and guarantee a future sustainable system as a minimum criterion for mutual recognition and acceptance of the national pharmaceutical inspectorate by the European Economic Area (EEA) member countries as well as with and by other pharmaceutical inspectorates outside the national framework. Recognizing, primarily, the need for a number of activities to be undertaken with the aim of implementing the policy on inspectorates quality systems and of achieving the objectives of the function, WHO, PIC/S (The Pharmaceutical Inspection Convention and Pharmaceutical Inspection Co-operation Scheme) and EMA (European Medicines Agency) have published a framework for the essential requirements (conditions) with regard to a quality system that will help the pharmaceutical inspection services to develop their own quality systems and to be recognized by other national pharmaceutical authorities.

\section{Elements in the Building of a Quality System for the Pharmaceutical Inspectorate (PhI)}

\section{Administrative Structure, Organization and Management of Pharmaceutical Inspectorates}

The policy on the quality of inspection services should be rooted in the basic principles set out in the Law on Inspection Supervision: legality, public interest, equality, independence, impartiality, transparency, objectivity, principles of material truth, prevention, proportionality and subsidiarity (OGRM, 2010). All these principles shall be reflected in concrete quality requirements established for the given inspectorate. The Pharmaceutical Inspectorate management structure should be officially committed to support the recommended quality system requirements by ensuring that the quality policy of the inspectorate is documented, that it is relevant to its objectives and that it is implemented. Furthermore, the Pharmaceutical Inspectorate management structure should have sufficient resources and competent staff at all levels, to ensure effective and successful functioning, and it should nominate a person to carry out the quality assurance function (quality system implementation and maintenance) and to perform periodical revisions of the quality systems.

The primary need with regard to the administrative structure and organization is to have clearly defined and documented procedures and criteria for the selection of persons, advisory committees, agencies or organizations to perform certain delegated activities as set out in a contract (this applies to persons who are part of the inspectorate, a regulatory body in the area of medicines or sub-contracted experts). The criteria to be met in the selection or employment of the $\mathrm{PhI}$ personnel should be:

- available as a written document and available to the public, and stating at least the required professional qualifications (e.g. pharmacist, physician, chemist and the like);

- $\quad$ stating precise data on the minimum years of past experience;

- $\quad$ supported by recommendations from professional associations, previous positions, and employment of the candidate for inspector;

- $\quad$ supported by testimonials to successful completion of inspectors trainings.

Inspectors' job descriptions, responsibilities, and authorities, as well as the reporting structure, should be clearly defined and documented in rulebooks. The structure should be defined in organization charts and supported by job descriptions for each member of the PhI staff. The rules for deontology, ethics and conflict of interests (OGRM, 2007c) should be clearly defined for both the PhI staff and the persons performing (or sub-contracted to perform) certain assignments for the inspectorate. The system for obtaining fees must not influence the quality of inspection. All cases requiring joint supervision shall follow a documented procedure for the cooperation between the inspectorate and other agencies and/or sub-contracted experts. The inspectorate shall implement a policy of distinguishing between inspection supervision and providing of advisory services to the clients.

\section{Human Resources - Inspectors}

Financial stability and sources of finances and technical assistance are clearly essential for the unhampered functioning of the inspection services. In distributing the resources and in determining the priorities, the Pharmaceutical Inspectorates should apply the principle of risk assessment and risk management. However, inspectors are an equally important element in the successful functioning of the supervision. Inspectorates need to have sufficient available personnel with adequate qualifications, competences, technical skills, specialized training, knowledge based on experience in performing inspection activities, and such that meet the specific requirements and standards (EMEA, 2007). Inspection services should guarantee that the personnel engaged is free from any "external" or "internal" influences of commercial, financial or any other nature that might affect the quality of their performance (ORGM, 2001 and OGRM, 2006). Personal integrity, maturity, transparency, understanding of the complexity of the subject, the ability to make a sound and complete judgment, as well as confidence, consistency, the ability to see given situation in a realistic way and practice their analytical skills, are just some of the principal traits inspectors have to possess. As regards inspector's personal qualities, it should be noted that during the inspection supervision inspectors should create an atmosphere of openness and transparency, give objective answers to all questions and offer explanations when needed in the course of the inspection, while being mindful not to assume the role of consultants.

Inspection supervision is performed by trained inspectors with experience in, for instance, medicines produc- 
tion, medicines quality control, pharmaceutical work etc. Inspectors shall have acquired their skills and been trained in accordance with the internationally adopted guidelines and programs of the agencies such as: The Pharmaceutical Inspection Convention/ Pharmaceutical Inspection Co-operation Scheme, and the European Compliance Academy ECA. They shall perform their activities in a highly professional manner demonstrating integrity and honesty.

\section{Inspectors' Qualifications and Training}

Inspectors' qualification is on an equal level with the qualification for any other qualified person (QP- Qualified person) which means that, in essence, they need to possess real knowledge of national and EU legislation. Their basic training for inspectors should cover a number of areas and enable them to acquire knowledge in:

- national and EU medicines-related legislation;

- technical standards such as GMP, GCP, GQCLP, GSP, GDP, GPP, guides relating to ethical advertising of medicines, etc;

- principles of quality assurance and quality management systems (EN, ISO standards);

- technical aspects of medicines production (expertise in pharmaceutical technology, processes and HVAC-systems, validation, computerized systems, analytical instruments, microbiology etc);

- organization and quality systems for competent authorities/inspectorates and training in compliance with the relevant national and international standards, operational procedures (SOPs) and procedures related to inspection supervision;

- marketing systems and production authorization and the relationship between the two;

- regulation of the cooperation relations in the sphere of licensing, inspection, sampling procedure and analyses;

- knowledge of the agreements with the Medicines Regulatory Agencies and EU agreements;

- inspection techniques acquired through participation in relevant trainings and/or in the presence and/or run by qualified inspectors;

- administrative procedures: management of planning, organization, communications or providing answers to the entity subjected to inspection supervision with regard to the process of evaluation of the existing situation and notification thereof;

- medicines development: QRM (Quality Risk Management), PQS (Pharmaceutical Quality System) (ICH Q8,Q9, Q10); international organizations and their activities - EDQM (European Directorate for the Quality of Medicines and Health Care), ICH (International Conference on Harmonization), $\mathrm{PIC} / \mathrm{S}, \mathrm{WHO}$;

- knowledge of other methodologies applicable in the achievement of quality assurance principles.
The national inspectorates may, when necessary, organize training in inspection supervision techniques, communication skills and notification skills, technical terms used in communication, legal aspects and management aspects.

Inspectors' continued training and maintenance of their competences are achieved through a variety of forms including: participation in training courses, seminars, professional committees and conferences organized by national and international scholarly and professional organizations (on subjects such as new production technologies, computerized systems); use of relevant sources of information, methods of joint inspections, or visits for training in other countries members of the EU etc.

Further continued training of inspectors can be run by senior inspectors, who will instruct them on the theory of inspection supervision using practical, concrete and reallife case studies and will discuss with them the importance and purposes of the inspection supervision.

In maintaining their competence inspectors shall be subjected to periodical knowledge assessments consistent with the requirements of the national legislation and the inspection services quality system.

\section{Documentation in Inspectorates}

Pharmaceutical inspectorates should establish and maintain a system for control of all documentation, recording of relevant documents and handling of documents, timeframe for the keeping of superseded and/or replaced documents, current versions previously approved by an authorized person, available versions kept by nominated inspectors. The existence of mechanisms for identification of any changes to documents, the controlled manner in which changes are made for the purposes of documents faster updating and approval by the authorized person, and for withdrawal and filing of the changed documents - such mechanisms are necessary in good documents management. Pharmaceutical inspectorates should prepare and regularly upgrade Inspectorate Quality Manual, incorporating all the elements of the quality system, and serving as a source of all referential working materials to be used as guides in inspectors' individual performances of their inspection activities. These Guides shall guarantee consistency and transparency of the inspection supervision process, as well as prevention of subjectivity in the performance of the supervision activities. On the other hand, written guides for inspection services shall be of great help in the assessment of inspectors' performance of their activities in compliance with the guides and the procedures. The pharmaceutical inspection service Quality Manual may contain samples of forms used in inspection supervision: check list used in the performance of inspection supervision, certificates, reports and examples of their processing, keeping, filing and disposal. In the area of good document keeping it is also necessary to set up a system for preparation of reports (as re- 
quired under the national legislation) related to the activities of the inspection service. Where relevant, documents from applicants for or holders of licenses shall also be included into the system. The reports refer to: detailed information on inspection supervision planning, description of the manner in which each inspection supervision was performed, follow-up activities after inspection supervision, sanctions imposed, and recommendations addressed to the body in charge of issuing licenses. All reports shall be considered confidential, unless otherwise regulated under the laws on free access to information (OGRM, 2006).

\section{Internal audit and quality improvement by means of cor- rective/preventive actions and handling of complaints}

The improvement of the quality of inspection supervision, or of the Pharmaceutical Inspectorate, is achieved by establishment of quality indicators related to both the inspectorate activities and the procedures for the analysis of the deviation from the quality system ascertained by external or internal audits carried out by the inspectorate. Periodic audits of the Pharmaceutical Inspectorate activities are necessary to assess compliance with the requirements of the quality system. The results of the audits and the corrective measures taken are reviewed by the management as part of the management review process. The processes and the documents relating to the audit processes, as well as the auditors qualifications, should be clearly defined. The reports should be kept for a defined period of time.

The procedure for corrective/preventive actions should include prescribing, implementation and verification of the corrective actions resulting from reports, investigation of complaints and other observations relating to inspectors' activities. The Pharmaceutical Inspectorate should establish a procedure for the investigation of complaints regarding the activities of the inspection services, its personnel, persons or organizations sub-contracted by the inspectorate, as well as written procedure on filing complaints against first instance decisions and a guide for complaints management.

\section{Other elements related to the requirements for a quality system for Pharmaceutical Inspectorate}

A sustainable quality system requires that the following requirements be established, documented and implemented:

- requirement to establish a system for the issue or withdrawal of licenses or GMP certificate or, where appropriate, for advising on the issue or withdrawal of licenses or GMP certificate (in accordance with the national and EU legislations);

- $\quad$ requirement to define the time limits within which the assessment shall be carried out;

- $\quad$ requirement to establish a system under which appropriate actions will be taken in cases of an ad- verse inspection report, with description of the actions to be taken;

- requirement to define the liaisons in the licensing system when it is not part of the pharmaceutical sector functions;

- $\quad$ requirement to establish a system for handling of reports on suspected defects in medicinal products, based on QRM;

- $\quad$ requirement to establish a Rapid Alert System RAS;

- requirement to establish, maintain and update a list of recalls;

- requirement to legally define the liaison with an official lab for the purposes of medicines control; requirement to exchange information concerning medicines or procedures of taking samples from starting materials for the production or for medicinal products, as per validated SOPs.

\section{Inspection Supervision - Methods, Strategies and Docu- menting}

At a global level, inspectors perform two types of inspection supervision: (I) in the period before licensing, and (II) in the period after licensing. The role of inspection supervision in the period before licensing is as follows:

- $\quad$ to evaluate the compliance with the requirements specified in the guides with regard to business capacities, spatial capacities, personnel, equipment, processes etc.;

- $\quad$ to evaluate the implemented procedures and methods of control used in the production, import, export, distribution etc.;

- $\quad$ to evaluate the completeness and accuracy of the information provided by the applicant.

The information gathered in the process of inspection supervision in the period before licensing is a very important segment in the evaluation of the application for registration and approval. The purpose of inspection supervision following licensing is to check the continuity in ensuring compliance with the approved standards, guidelines, procedures and the national regulations on medicines. Depending on the purpose of the inspection supervision, the inspectors apply a number of methods for supervision of pharmaceutical capacities, including:

- comprehensive or routine inspections;

- concise inspections;

- follow-up inspections;

- $\quad$ special inspections; and

- $\quad$ investigative inspections.

The strategies used in the process of inspection, with the aim of achieving a higher level of objectivity and reducing the possibilities for unethical practices in supervision to a minimum, include: 
- inspection supervision by a team of inspectors with a selected chief inspector leading the team;

- rotation of inspectors, by means of a system for development of inspection supervision schedule;

- rotation of inspectors in different geographic areas;

- inspection supervision carried out in the presence of a peer inspector that will write a report on the inspector's work; and

- external assessment, i.e. independent evaluation of the inspection supervision.

The inspector is required to submit his report with recommendations to the inspection authorities that will evaluate its compliance with the guidelines and procedures. The recommendations should be subjected to substantial evaluation with regard to possible contradictions in the findings ascertained during the inspection process and/or possible ambiguity and unclear formulations. In addition, it is necessary to confirm that the inspector has discussed his/her findings with the responsible representatives of the management of the applicant subjected to inspection supervision, and thus met the requirement for transparency of inspection. Inspection supervision should represent a well documented procedure based on relevant laws and regulations the aim of which it is to enable supervision (as in the cases of production and distribution operations), in conformity with the national legislation, the official guidelines and the formal inspection plan. The set of documents should include: written instructions, written standards and procedures, work sheets, references etc. The documents shall be regularly updated and made easily available to the personnel.

It is necessary to distinguish between whether the inspection supervision was performed by a team of inspectors or by one inspector, and to see if the report (in a defined format) was adequately prepared by a person authorized to prepare the report, in the case of a team. Furthermore, the subject of inspection supervision should authorize a person that will receive the report, which is a qualified person $(\mathrm{QP})$.

\section{Guidelines for management of conflicts of interests and for declaration of conflict of interests}

An inspector must not use his/her official powers to obtain privileges of any nature, including those associated with financial, commercial and other interests incompatible with his/her job description and duties. These strict requirements apply also to the members of his/her family, friends and associates. The minimum criteria in the written guides on conflict of interest management and for the declaration of a conflict of interests should include the following elements:

- definition of all situations that represent conflicts of interests in the inspector's job description;

- $\quad$ rules on the acceptance of gifts;
- rules on declaring interests;

- a mechanism for protection of the persons informing on the existence of a conflict of interests;

- actions to be undertaken in cases of ascertained omissions and breaches in the adherence to the principle and in conflicts of interests management;

- $\quad$ evidence of the continuous and systematic updating of information by inspectors and civil servants involved in the inspection supervision.

All these elements of the pharmaceutical inspection supervision represent obligations arising from the Law on Inspection Supervision of the Republic of Macedonia (OGRM, 2010) and the adequate bylaws. The permanent process of developing and establishment of concrete requirements and recommendations ensuing from this Law includes reducing any possibilities for their inefficient implementation in practice to the minimum.

\section{References}

EMEA, 2007. Guideline on Training and Qualifications of GMP Inspectors (http://www.gmpcompliance.org/eca_news_1336 5865,5592,5816,5587,5946.html)

IDPI, 2009. International Drug Price Indicator Guide (http://erc. msh.org/dmpguide/pdf/DrugPriceGuide_2010_en.pdf).

ORGM, 2001. Civil Servants Code of Ethics (Official Gazette of RM No бp.96/2001; Code to supplement the Civil Servants Code of Ethics, 16/2004; 48/2007).

OGRM, 2006. Law on Free Access to Information of Public Interest (Official Gazette of RM No. 13/2006; latest amendment 14 July 2008).

OGRM, 2007a. Law on Public Procurements (Official Gazette of RM No. 136/2007 and amendments: 130/08; 97/10;53/11).

OGRM, 2007b. Law on Medicines and Medicinal Devices (Official Gazette of RM No.106, of 5 September 2007; amendments 15 and 16 July 2010.

OGRM, 2007c. Law on Prevention of Conflicts of Interests (Official Gazette of RM No.70/2007;114/2009- statement of interests.

OGRM, 2010. Law on Inspection Supervision (Official Gazette of RM No. 50 of 13 April 2010; implementation as of 1 April 2011).

PIC/S, 2007. Recommendation on Quality Systems Requirements for Pharmaceutical Inspectorates (http://www.ccd.org.cn/ ccd/fs/web_edit_file/20110510141908.pdf).

WHO, 1999. Operational Principles for Good Pharmaceutical Procurement, Essential Drugs and Medicines Policy, Interagency Pharmaceutical Coordination Group,WHO/ EDM/PAR/99(http://www.who.int/3by5/en/who-edm-par99-5.pdf).

WHO, 2004. Priority medicines for Europe and the World, Essential Drugs and Medicines Policy, Ed.WHO, pp23-28

WHO, 2010. Model List of Essential Medicines List, $16^{\text {th }}$ (updated) March (http://whqlibdoc.who.int/hq/2010/a95060_eng.pdf). 


\title{
Резиме
}

\section{Хармонизација на Инспекцискиот надзор во фармацевтскиот сектор во Република Македонија согласно препораките на европската регулатива и С30}

\author{
Василка Нича, Рената Славеска Раички и Татјана Кадифкова Пановска \\ Јавна установа од областа на здравството за потребите ЈЗУ Универзитетски Клиники, Завод и \\ ургенетен иентар, Скопје \\ Фармаиевтски факултет, УКИМ, Скопје
}

Клучни зборови: фармацевтски инспекциски надзор

Новиот Закон за инспекциски надзор (Службен весник 50/2010, имплементација од 2011/04/01) беше донесен во април 2010 година со цел да се унапреди квалитетот на инспекцискиот надзор и во фармацевтскиот сектор. Новиот Закон покрива спектар на тековно идентификувани слабости.

Системот за квалитет на инспекцискиот надзор обединува збир од основни барања за квалитет во управување со процесот, цели, услови, политики, официјални закони и процедури. Организациската шема се однесува на сите аспекти на инспекциските активности. Инспекциската служба мора да гарантира дека нејзиниот персонал не е под било какви внатрешни или надворешни трговски, финансиски или друг вид на притисоци и несоодветни влијание кои што може негативно да влијае на квалитетот на нивната работа.

За извршување на инспекцискииот надзор во согласност со спецофичните барања и стандарди, инспекциската служба треба да располага со доволен број на вработен персонал кој ги поседува потребните степени на образование, обука, техничко познавање и искуство. Ангажираноста на инспекторот треба да е во рамките на одговорностите кои што произлегуваат од неговите/ нејзините активности. Потребно е да се востанови континуирана обука за инспекциските активности вклучувајќ ги и напредните програми за обука кои нудат различни нивоа на квалификација на инспекторите.

Во блиска иднина, се наметнува потреба од развивање и усвојување на правилници со кои ќе се регулира инспекцискиот надзор во фармацевтскиот сектор во однос на нивната специфична активност.

Овој процес на перманентно надградување на постоечката национална релулатива согласно легалните политики на Европската Унија е една од карактеристиките на фармацевтскиот сектор во Р. Македонија. 
